\title{
Echocardiographic Evaluation of Anatomical Abnormalities of Interventricular Septum (with Special Reference to Ventricular Septal Defect) in the Population of West Bengal between 1 and 12 Years of Age
}

\author{
Arpan Kumar Goswami1 ${ }^{1}$, Dhruba Mandal2 ${ }^{2}$ Shruti Goswami ${ }^{3}$, Biswajit Majumdar, Adrija Mandal ${ }^{5}$
}

\begin{abstract}
${ }^{1}$ Assistant Professor, Department of Anatomy, Bankura Sammilani Medical College, Bankura, West Bengal, India. ${ }^{2}$ Associate Professor, Department of Anatomy, Bankura Sammilani Medical College, Bankura, West Bengal, India. ${ }^{3}$ Scholar, Tripura Medical College, Agartala, Tripura, India. ${ }^{4}$ Associate Professor Department of Cardiology, R.G. Kar Medical College, Kolkata, West Bengal, India. ${ }^{5}$ Scholar, Burdwan Model School, Purba Bardhaman, West Bengal, India.
\end{abstract}

\section{ABSTRACT}

\section{BACKGROUND}

Right and left ventricles of human heart are separated by interventricular septum. The septum develops in early embryonic period from three sources: primitive ventricular septum, bulbar septum and endocardial cushion. Primitive ventricular septum forms the major part of muscular septum, some contribution comes from bulbar septum. Endocardial cushion forms the membranous part of ventricular septum. Obviously, these three parts fuse to form a complete septum. Sometimes they do not fuse properly, or one of them does not proliferate properly, leading to formation of a defective septum containing one or more foramina. This condition is called ventricular septal defect. Commonly, endocardial cushion does not proliferate properly producing defect in membranous septum. Less commonly foramina are situated in muscular septum. Perimembranous VSD is described as foramen lies in membranous septum and surrounding it, which is due to non-proliferation of endocardial cushion as stated above, and also due to non-fusion of two bulbar septi. So VSDs may be perimembranous or muscular. In the University of Padua, Itali, Dr. Gaetono Thiene dissected several cadaveric heart specimens and found many cases of VSDs. Among them, perimembranous VSD was the most common (90\%); some were muscular $(10 \%)$ and some were having more than one orifice $(10 \%)$. In our study, we try to find out the types of VSDs by echocardiography in living subjects and then compare it with the data of Dr. Gaetono Thiene.

\section{METHODS}

By simple random sampling method, two hundred patients of age group 1-12 years having clinical features of VSD were chosen in the Cardiology OPD, Nilratan Sircar Medical College, Kolkata, West Bengal, India. By echocardiography, VSD was confirmed along with its type. The findings were tabulated, and the data was statistically analysed.

\section{RESULTS}

We got $83 \%$ perimembranous VSD, $15.5 \%$ muscular VSD and $1.5 \%$ having more than one orifice in the ventricular septum.

\section{CONCLUSIONS}

Perimembranous VSD is so far the most common, next is the muscular VSD.

\section{KEY WORDS}

Embryology of Ventricular Septum, Perimembranous VSD, Muscular VSD, Echocardiography
Corresponding Author:

Dr. Dhruba Mandal,

Rabindrapalli,

Burdwan-713101,

West Bengal, India.

E-mail: mandaldhruba@yahoo.com

DOI: $10.14260 / \mathrm{jemds} / 2019 / 777$

Financial or Other Competing Interests: None.

How to Cite This Article:

Goswami AK, Mandal D, Goswami S, et al. Echocardiographic evaluation of anatomical abnormalities of interventricular septum (with special reference to ventricular septal defect) in population of west bengal between 1 and 12 years of age. J. Evolution Med. Dent. Sci. 2019;8(48):3599-3603, DOI:
Submission 12-09-2019,

Peer Review 11-11-2019,

Acceptance 19-11-2019,

Published 02-12-2019. 


\section{BACKGROUND}

Heart is the most important organ of our body. Its structure and evolution are thoroughly studied ${ }^{1}$. It is a muscular organ composed of special type of muscle called 'cardiac muscle.'2,3,4,5,6 It has got four chambers: two atria \& two ventricles. Right atrium \& right ventricle known as 'right heart' 7 receives less oxygenated (deoxygenated!) blood from different parts \& different organs of our body via veins, and the blood is pumped out into pulmonary circulation for oxygenation. The oxygenated blood received by left atrium \& left ventricle (so called 'left heart,', ${ }^{\text {) }}$ is ejected to different parts \& different organs via arteries. Human body is structurally \& functionally complex; so, it requires pure oxygenated blood. This means there would not be any mixing of arterial and venous blood (c.f. frog. ${ }^{9}$ ) So, there should be a strict partition between right \& left atria called interatrial septum simply atrial septum. Similarly, interventricular septum (simply ventricular septum) separates right ventricle from that of left. The developmental process of atrial \& ventricular septum is complex.10 Let us have a look on embryology of ventricular septum.

In the $3^{\text {rd }}$ week of intrauterine life, two endothelial heart tubes appear in the cardiogenic area of the embryo where heart will be formed, ${ }^{11}$ they fuse together forming a single heart tube. The heart tube consists of one venous end (caudal end) and another arterial end (cranial end). Soon it shows several dilations (from venous to arterial end): sinus venosus, primitive atrium, primitive ventricle and bulbous cordis. ${ }^{12}$ Primitive atrium \& primitive ventricle are connected by atrioventricular canal where dorsal \& ventral endocardial cushions appear. The cushions proliferate toward each other and fuse themselves forming the septum intermedium. Now the atrioventricular canal is divided into right \& left atrio-ventricular orifices. ${ }^{13}$

Distal one third of bulbus cordis is called truncus arteriosus which will form ascending aorta \& pulmonary trunk due to appearance of spiral septum inside it. As the heart tube folds itself, primitive ventricle \& proximal two third of bulbous cordis merge together to form a single chamber called bulboventricular cavity. The bulbo-ventricular cavity should be divided by a septum so that we will get right \& left ventricle. During late $5^{\text {th }}$ and early $6^{\text {th }}$ week of intrauterine life, ${ }^{14}$ a primitive interventricular septum arises from midway of the floor of bulbo-ventricular cavity. Its upper margin is crescentic. In the meantime, two ridges (right \& left) appear in the distal part (outflow part) of bulbo-ventricular cavity. The ridges proliferate and fuse themselves to form bulbar septum. Now distal part of bulbo-ventricular cavity is divided into outflow part of right \& left ventricle. The bulbar septum proliferates caudally toward primitive interventricular septum, but does not fuse with it. So, a gap or foramen remains in the ventricular septum. Now the endocardial cushion (septum intermedium) proliferates to fill the gap. Endocardial cushion forms the membranous part of ventricular septum. Interventricular septum becomes completely formed by $8^{\text {th }}$ week of intrauterine life. ${ }^{14}$

\section{Morphology of Ventricular Septum}

Left ventricular wall is thicker than that of right, as left ventricle has to work more. So, the ventricular septum has a convexity toward right. Hence on cross section, right ventricular cavity is semilunar, and that of left ventricle is circular. ${ }^{7}$ Major part of ventricular septum is muscular which occupies antero-inferiorly. ${ }^{15}$ Membranous part forms a small oval area on postero-superior part of the septum, below aortic semilunar valve ${ }^{7}$. Anatomically, muscular septum is divided into two regions: most portion is the inflow part of both ventricles, called inlet septum, ${ }^{8}$ it is thick, contains papillary muscles, and is derived from primitive interventricular septum. Another smaller portion is situated between the outflow tracts of right and left ventricles, called outlet septum; it is derived from bulbar septum. Left surface of outlet septum contains no muscle; but right surface contains muscle. Ventricular septum in placed obliquely so that its one surface looks forward and to the right, and other surface looks backward and to the left. ${ }^{15,16}$

In this context, a smooth ridge of myocardium called supraventricular ridge or crest is situated on the anterior wall of right ventricular cavity at the junction of rough inflow part and smooth outflow part (smooth part called infundibulum). The crest is thick, muscular and highly curved which extends downward and to the right from high ventricular septum to atrioventricular orifice ${ }^{7}$. Laterally, the crest gives attachment to the base of anterior cusp of tricuspid valve. Traced to the left, the crest fuses with ventricular septum at the junction of membranous septum \& bulbar septum. ${ }^{8}$

\section{Ventricular Septal Defects, its Embryological Explanation} The ventricular septum develops from fusion of three embryogenic components: primitive interventricular septum, bulbar septum \& endocardial cushion. Sometime one of these components is missing or maldeveloped, or these components do not fuse themselves properly. This leads to a gap or foramen called ventricular septal defect (VSD). ${ }^{14}$ Commonly endocardial cushion does not proliferate properly, producing a foramen in membranous part of ventricular septum. Sometimes left \& right bulbar ridges do not fuse themselves producing VSD. These two types of VSD are collectively called perimembranous VSD. Less commonly, foramen presents in the muscular part due to insufficient formation of muscular septum or breakdown of tissue after formation of ventricular septum. ${ }^{17}$ Regarding etiological point of view, VSD is seen in maternal condition like rubella infection, diabetes, phenytoin therapy etc. Genetic \& chromosomal abnormalities also have adverse effects like Marfan syndrome, Down syndrome, Turner syndrome etc. ${ }^{18}$

\section{Consequences of VSD}

As the left ventricle has to work against more pressure gradient its wall thicker than right ventricle. So initially blood is shunted to right ventricle from left ventricle. Right ventricle gets overloaded, so becomes hypertrophied and later on congestive cardiac failure supervenes. Pulmonary blood flow increases, and eventually pulmonary hypertension develops. Gradually blood will be shunted from right to left, cyanosis appears. ${ }^{18}$ This whole thing depends upon the size and type of VSD. Small VSD (Maladiede Roger, the term given by the famous paediatrician Henri Luis Roger in 1879, means small VSD) may remain unnoticed, causes little systemic disturbance ${ }^{18}$ and the person remains asymptomatic throughout his whole life. VSD may be diagnosed in childhood by non-invasive method like echo-cardiography. 
In the University of Padua, Itali, in 2005 Dr. Gaetono Thieneet al ${ }^{19}$ dissected 1400 human heart specimens, out of which 101 specimens were seen having VSD. They calculated the percentage of types of VSD as follows:

\begin{tabular}{|c|c|c|c|}
\hline Sl. No. & Type of VSD & No. of Specimens & Percentage \\
\hline 1 & Perimembranous & 81 & $80 \%$ \\
\hline 2 & Muscular & 10 & $10 \%$ \\
\hline \multirow[t]{2}{*}{3} & Multiple (trabecular) & 10 & $10 \%$ \\
\hline & Total & 101 & $100 \%$ \\
\hline
\end{tabular}

\begin{tabular}{|c|c|c|c|c|c|c|}
\hline $\begin{array}{l}\text { Sl. } \\
\text { No. }\end{array}$ & Type of VSD & \begin{tabular}{|c|} 
Frequency \\
(No. of Cases)
\end{tabular} & $\%$ & $\begin{array}{l}\text { Cumulative } \\
\text { Percentage }\end{array}$ & \multicolumn{2}{|c|}{\begin{tabular}{|c|}
$\begin{array}{c}95 \% \text { Confidence } \\
\text { Limit }\end{array}$ \\
\end{tabular}} \\
\hline 1 & Perimembranous & 166 & $83 \%$ & $83 \%$ & $77.1 \%$ & $87.9 \%$ \\
\hline 2 & Muscular & 31 & $15.5 \%$ & $98.5 \%$ & $10.8 \%$ & $21.3 \%$ \\
\hline 3 & Multiple & 3 & $1.5 \%$ & $100 \%$ & $0.3 \%$ & $4.3 \%$ \\
\hline & Total & 200 & $100 \%$ & $100 \%$ & & \\
\hline
\end{tabular}

The study was conducted in anatomical specimens of European cadavers. In our study, we are classifying VSD by echo-cardiography of living subjects of Indian population having isolated VSD and then compare the result with that of University of Padua. The idea came in mind from the Circulation 1958 by Fyler DC. ${ }^{20}$

\section{Why the Type of VSD is So Important?}

Spontaneous closure of VSD is possible. ${ }^{21,22}$ In the first five years of life, upto 30-50 percent of VSDs close spontaneously. ${ }^{19}$ Closure is more common in muscular VSD,23,24,25,26 either partially or completely, either by proliferation of surrounding tissue, or by hypertrophy of muscles or by cusp adhesion due to apposition of septal leaflet of tricuspid valve. Chance of closure is less in membranous VSD. ${ }^{27}$ So type of VSD is very important in view that surgical intervention may be avoided. ${ }^{28}$ More over this comparison study between occurrence of VSD in children and that of cadaveric VSD might once again prove that spontaneous closure of VSD is possible. Regarding surgical intervention, muscular VSD can be closed by transcatheter muscular VSD occlude. ${ }^{29}$ It works well and is safe, having lower cost. It is done through femoral artery in the groin. Perimembranous VSD are generally closed by open heart surgery, because percutaneous device leads to partial or complete heart block due device trauma over AV node. ${ }^{30}$

\section{METHODS}

Before starting collection of samples, we took ethical committee clearance from the respective medical college. Clinically suspected cases of VSD were selected in the cardiology OPD of Nilratan Sircar Medical College \& Hospital. Provisional diagnosis was made by cardiologists by auscultation of chest having heart murmur. Smaller defect produces loud pansystolic murmur at the left sternal border because of high pressure flow between two ventricles. ${ }^{19}$

Larger defect produces soft systolic murmur as the ventricular pressure gradient is equalised early, generally within two months of age. So, these babies present with congestive heart failure. ${ }^{19}$

Age group was taken between 1-12 years of age. Actually, these children were referred from paediatric medicine OPD, having history of recurrent respiratory infection, stunted growth, palpitation, poor weight gain etc. ${ }^{31}$ Total 200 cases were taken irrespective of sex. Prevalence of VSD is 1.7 in 1000 live birth. ${ }^{18,32}$ We know sample size $=4 \mathrm{pq} / \mathrm{L}^{2}$ where $\mathrm{p}=$ prevalence, $\mathrm{q}=100-\mathrm{p}, \mathrm{L}=$ error $^{33}$ So minimum 200 samples are required. We took informed consent from the parents of the patients. These patients were advised for echocardiography with 2D mode. We considered only the isolated VSD cases. They are categorised as perimembranous, muscular and multiple VSD. The results are tabulated and statistically analysed.

\section{Inclusion Criteria}

1. Age group between 1 to 12 years

2. Irrespective of sex

3. Isolated VSD without any other congenital heart defect e.g. atrial septal defect (ASD), pulmonary stenosis (PS), Fallot's tetralogy etc.

\section{Exclusion Criteria}

1. Age below one year or more than 12 years

2. VSD complicated with ASD, PS, Fallot's tetralogy, pulmonary hypertension etc.

\section{Echocardiographic Evaluation of VSD}

In living subject, structure of the heart and its association among its different parts can be studied by an instrument called echocardiography machine.3,4 Ultrasound is passed through the heart by a transducer and the echoes are detected by echo-cardiography machine according to constructional and quantitative tissue of the heart. So cross sectional views are obtained: longitudinal, transverse or oblique by displacing the transducer. Multiple views are required especially for ventricular septum, because ventricular septum is curved with convexity toward right, 7 so a single imaging plane will neither interrogate the complete structure nor detect every defect. By this way pictures are obtained showing chambers of the heart (two atria \& two ventricles), ventricular septum its different regions, orifices of great arteries (ascending aorta \& pulmonary trunk). Echocardiographically, ventricular septum can be divided into- Membranous Septum (located directly below aortic valve) and Muscular Septum. Muscular septum is further subdivided into- Inlet Septum (situated posterior to membranous septum between atrio-ventricular valves), Trabecular Septum (extends from membranous septum to cardiac apex) and Outlet Septum (extends anteriorly from membranous septum, lying above trabecular septum and below great arteries).

So VSD can be detected, its types and size. Accuracy of echo-cardiography for detecting a VSD depends on its size and location. VSD is hardly confined to membranous septum, but more often extends to surrounding muscular region. So perimembranous VSD is preferred terminology to membranous VSD. In general, false negative results are more common than false positive results. Sensitivity of twodimensional echocardiography for diagnosis of VSD depends on its location: highest (nearly 100\%) for inlet \& outlet defects, slightly less (80-90\%) for perimembranous defects and least (50\%) for trabecular defect. But the sensitivity has become considerably higher with modern equipment and techniques.

Perimembranous VSD is located at the intersection of trabecular, inlet and outlet region of the septum, just beneath 
the aortic valve and behind the septal leaflet of tricuspid valve, as seen in the parasternal long axis echocardiographic view. This defect can also be seen apical and subcostal view.

Muscular defects are occasionally multiple. Smaller defects are difficult to identify within trabeculation of right ventricle. Defects in the apical septum are most likely to be missed. This is to overcome by obtaining serial sections of the ventricle from apex to base.

Subpulmonary defects are located below the pulmonary valves and above the crista supraventricularis. Although they may be difficult to distinguish from membranous defects in long axis view of 2D echocardiogram, they are easily identified in parasternal short axis images obtained at the level of the arterial root.

Inlet defects occur at the crux of the heart, posterior and inferior to membranous and outlet defects, and at the junction of atrioventricular valves. These are best demonstrated in apical and subcostal coronal views (short axis).

The relationship of the atrioventricular valves to the VSD carefully assessed by tracing tricuspid valve chordal attachments which commonly inserts on the crest of the right ventricular surface of the septum. Anomalous chordal attachments of the mitral valve may also insert on the septum. Special attention was given to three main components of ventricular septum ${ }^{34}$ - the septum of $\mathrm{AV}$ canal, the muscular septum and the parietal band or distal conal septum.

All findings were repeated by two independent observers to identify any intra- or inter-observer variation. Data collected by this method are tabulated and statistically analysed.

\section{RESULTS}

In this study of 200 cases of VSD, we got perimembranous defect in 166 patients (83\%), muscular defect in 31 patients $(15.5 \%)$ and multiple defects in 3 patients $(1.5 \%)$

\section{DISCUSSION}

Most common birth defects are cardiovascular in origin. ${ }^{32}$ Ventricular septal defect (VSD) is so far the commonest congenital heart disease (About 12 in 10,000 live births). ${ }^{18,32}$ It leads to stunted growth of the children, palpitation, recurrent respiratory infection, cyanosis etc. Early diagnosis of VSD may be missed. These children are initially examined by paediatricians. So, the paediatrician has got the vital role in early diagnosis of CHD in children, so that they can refer these children to the cardiologist/cardiac surgeon at an early age. These children are evaluated by cardiologist by echocardiography, to make proper diagnosis what type of CHD the child is suffering from. The congenital heart diseases may be in the form of ventricular septal defect, atrial septal defect, tetralogy of Fallot etc. So far concerned VSD is the commonest one. Ventricular septum is mostly muscular, a small portion is membranous. Due to defect in developmental process, a foramen or orifice may be seen in the ventricular septum. The defect lies mostly in membranous septum. ${ }^{19}$ It is well known that VSD especially muscular defect may close spontaneously, by growth or proliferation of the surrounding tissue, depending upon the size of the VSD. Closure is seen till first five year of life and also thereafter. So early identification of type of VSD may predict the mode of treatment and surgical intervention may be deferred in some cases keeping in hope of spontaneous closure of VSD. ${ }^{22,24,25,26}$ In this context this may be mentioned that in 1892, Sir William Osler, ${ }^{21}$ in his text book "The Principles and Practice of Medicine" wrote a few pages on 'Congenital Affection of the Heart'. The first sentence was like this: these disorders have only limited clinical interest, as in large population of cases the anomalies are not compatible with life, and in others nothing can be done to remedy the defect or even to relieve symptoms. Fortunately, in new era of medicine, considerable progress has been made in understanding and treatment of congenital heart diseases. ${ }^{32}$

In our study, we took 200 cases having isolated VSD in paediatric age group. The diagnosis was made by echocardiography. We tried to find out number of cases having perimembranous, muscular or multiple defects, and then compare our results with the study on cadavers done by Dr. Gaetono Thiene, University of Padua, USA. Percentage of perimembranous VSD is same as that of Dr. Thiene. Percentage of muscular VSD is slightly more; but multiple defect is far less (only $1.5 \%$ ) in comparison to Pedua study (10\%). This may be due the following facts-

1. Multiple defects may be less in Indian population in comparison to European population.

2. In our study, population was chosen between $1-12$ years age group, foramen may be obliterated early.

3. Multiple defects may be missed during echocardiography if not done very carefully.

\section{CONCLUSIONS}

Perimembranous VSD is so far the most common type of ventricular septal defect.

\section{REFERENCES}

[1] Bishopric NH. Evolution of the heart from bacteria to man. Ann N Y Acad Sci 2005;1047(4):13-29.

[2] Eroschenko VP. De Fiore's Atlas of Histology with clinical correlation. 13 ${ }^{\text {th }}$ edn. Wolters-Kluwer 2017: p. 154.

[3] Vasudeva N, Mishra S. Inderbir Singh's Textbook of Human histology with color atlas and practical guide. $8^{\text {th }}$ edn. Jaypee 2016: p. 75.

[4] Sontakke Y. Textbook of Human histology. $1^{\text {st }}$ edn. CBS Publisher 2020: p. 100.

[5] Kumar B. Histology Text \& Atlas. $4^{\text {th }}$ edn. Wolters Kluwer 2016: p. 119.

[6] Datta AK. Functional histology. 1'st edn. Current Book International 2015: p. 82.

[7] Datta AK. Essential of human anatomy. Thorax and Abdomen. $9^{\text {th }}$ edn. Current Book International 2010: p. 62, 74.

[8] Standring S. Gray's Anatomy: the anatomical basis of clinical practice. $40^{\text {th }}$ edn. Churchill Livingstone 2008: $p$. $1774,1769$. 
[9] Kimball JW. Biology. $5^{\text {th }}$ edn. Addison Wesley Longman 1983.

[10] Moore KL, Persaud TVN. The developing human. Clinically oriented embryology. $8^{\text {th }}$ edn. Saunders Elsevier 2007: p. 285-319.

[11] Singh I. Human embryology. 10 $0^{\text {th }}$ edn. Jaypee Brothers Medical Publishers 2014: p. 281.

[12] Kumar B. Embryology Text \& Atlas. 1st edn. Wolters Kluwer 2017: p. 88.

[13] Sontakke Y. Textbook of Human embryology. $1^{\text {st }}$ edn. CBS Publisher 2019: p. 173.

[14] Datta AK. Essential of human embryology. $7^{\text {th }}$ edn. Current Book International 2017: p. 173, 179.

[15] Mehta V, Suri RK. Snell's Clinical anatomy. Wolters Kluwer 2018: p. 99.

[16] Garg K, Mittal P, Chandrupatla M. B. D. Chaurasia's Human Anatomy. Regional and applied, upper limb and thorax. $8^{\text {th }}$ edn. CBS Publisher \& Distributors Pvt Ltd., 2020: p. 291.

[17] Scoenwolf GC, Bleyl SB, Brauer PR, et al. Larsen's Human embryology. $4^{\text {th }}$ edn. Elsevier/ Churchill Livingstone 2009: p. 382.

[18] William NS, Bulstrode CKJ, O'Connell PR. Bailey \& Love's Short practice of surgery. $26^{\text {th }}$ edn. CRC Press Taylor \& Francis Group 2013: p. 841, 844-5.

[19] Gaetano T. Segmental approach to logical diagnosis, simple shunt lesion: diagnosis imaging interventricular septal defect anatomy. 2005: p 7-10.

[20] Fyler DC, Rudloph AM, Wittenborg MH, et al. Ventricular septal defect in infant and children: a correlation of clinical, physiologic and autopsy data. Circulation 1958;18(5):833-51.

[21] Oscar W. The principles and practice of medicine. New York: Appleton \& Co, 1892: p. 659-63.

[22] Onat T, Ahunbay G, Batmaz G, et al. The natural closure of isolated ventricular defect during adolescence. Pediatr Cardio 1998;19(3):230-4.

[23] Evans JR, Rowe RD, Keith JD. Spontaneous closure of Ventricular septal defect. Circulation 1960;22:1044-54.
[24] Meberg A, Otterstad JE, Froland G, et al. Increasing incidence of ventricular septal defects caused by improved detection rate. Acta Paeditr 1994;83(6):653-7.

[25] Hiraishi S, Agata Y, Nowatari M, et al. Incidence and natural course of trabecular ventricular septal defect: two-dimensional echocardiography and color Doppler flow imaging study. The Journal of Paediatrics 1992;120(3):409-15.

[26] Roguin N, Du ZD, Barak M, et al. High prevalence of muscular ventricular septal defect in neonates. Journal of the American College of Cardiology 1995;26(6):1545-8.

[27] Eroglu AG, Oztunc F, Saltik et al. Evolution of Ventricular septal defect with special reference to spontaneous closure rate, subaortic ridge and aortic valve prolapse. Pediatric Cardiology 2003;24(1):31-5.

[28] Chengo TO, Xie MX, Wang XF. Real-time 3-dimentional echocardiography in assessing atrial and ventricular septal defect: an echocardiographic-surgical correlative study. Am Heart J 2004;148(6):1091-5.

[29] Fu YC. Transcatheter device closure of muscular ventricular septal defect. Paediatrics and Neonatology 2011;52(1):3-4.

[30] Szkutnik M, Qureshi SA, Kusa J, et al. Use of the Amplatzer muscular ventricular septal defect occlude for closure of perimembranous ventricular septal defects. Heart 2007;93(3):355-8.

[31] Ghai OP, Paul VK, Bagga A. Ghai's Essential of pediatrics. 7th edn. CBS Publications 2010: p. 402-4.

[32] Longo D, Fauci A, Kasper D, et al. Harrison's Principles of Internal Medicine. $18^{\text {th }}$ edn. McGraw-Hill 2012: p. 1920, 1923.

[33] Park K. Park's Text book of Preventive and social medicine. 21 st edn. Jabalpur: Bhanot Publisher 2013: p. 57-8.

[34] Van Praagh R, Geva T, Kreutzer J. Ventricular septal defects: how shall we describe, name and classify them? J Am Coll Cardiol 1989;14(5):1298-9. 